\title{
doi.org/10.46291/ISPECIJSSHvol4iss3pp145-166
}

\section{Üniversite Öğrencilerinin İşsizlik Kaygısı}

\author{
Aylin SURAT \\ Nevşehir Hacı Bektaş Veli Üniversitesi, İktisadi ve İdari Bilimler Fakültesi, \\ Nevşehir, Türkiye, aylin@nevsehir.edu.tr
}

\section{Dilek CERAN}

Nevşehir Hacı Bektaş Veli Üniversitesi, Fen Edebiyat Fakültesi, Nevşehir, Türkiye, cerand@nevsehir.edu.tr

\begin{abstract}
Özet
Birey tedirginlik, endişe ya da kötü bir şey olacakmış duygusu yaşadığında hissettiği kaygı duygusudur. Türkiye ve dünyada en büyük sorunlardan biri olan işsizlik iş arayan bireylerde işsizlik kaygısına yol açmaktadır. Üniversite son sınıf öğrencilerinde gelecekte mezun olduktan sonra iş bulamayacak olma düşüncesi ve iş belirsizliği öğrencilerin işsizlik kaygısı yaşamalarına neden olmaktadır. Bu çalışmanın amacı, üniversite son sınıf öğrencilerinin işsizlik kaygısı yaşayıp yaşamadıklarını belirlemek ve demografik özelliklere göre öğrencilerin işsizlik kaygıları arasında farklılık olup olmadığını araştırmaktır. Çalışma, Nevşehir Hacı Bektaş Veli Üniversitesi Fen Edebiyat Fakültesi'nde öğrenim gören toplam 139 son sınıf lisans öğrencisine uygulanmıştır. Öğrencilerin işsizlik kaygı düzeyini ve demografik özelliklerini belirleyen bir anket çalışması yapılmıştır. Cevaplar SPSS paket programına girilerek araştırma hipotezleri test edilmeye çalışılmıştır. Çalışmada değişkenleri sınıflamada çok değişkenli istatistiksel analizlerden faktör analizi uygulanmıştır. Çalışmanın hipotezlerinin sınanmasında istatistiksel analiz tekniklerinden tek yönlü varyans analizi ve bağımsız örneklemler $\mathrm{t}$ testi kullanılmıştır. İşsizlik kaygısı alt boyutları belirlenerek alt boyutlarında farklılıkların değerlendirmeleri yapılmaya çalışılmıştır. Demografik özelliklerden alana, bölümlere, cinsiyete, yerleşim yerlerine ve genel not ortalamasına göre işsizlik kaygısı boyutlarında farklılık olduğu belirlenmiştir.
\end{abstract}

Anahtar Kelimeler: İşsizlik, Genç işsizlik, İşsizlik kaygısı, Üniversite öğrencileri

\section{Unemployment Anxiety of University Students}

\begin{abstract}
When an individual have the feeling that something bad will happen, concern or apprehension, the feeling he/she feels perceive of anxiety. In Turkey and the world unemployment which is one of the biggest problems causes unemployment anxiety in job seekers. The idea of not finding a job after graduation in university senior students and job uncertainty causes students to experience unemployment anxiety. The aim of the study is to establish whether university senior students experience unemployment anxiety and to investigate whether there is a difference between unemployment anxiety of students with respect to demographic characteristics. The study was applied
\end{abstract}

Year 4/ 2020, Volume-4, Issue-3 | www.ispecjournal.org 
to a total of 139 senior students at Nevşehir Hacı Bektaş Veli University Faculty of Art and Science. A questionnaire was conducted to establish the level of unemployment anxiety and demographic characteristics of students. The data were typed into the SPSS package program and tried to test the research hypotheses. In the study, factor analysis, which is one of the multivariate statistical analyzes, was used to classify the variables. Independent samples t-test and one-way analysis of variance were used to examine the hypotheses of the study. To evaluate the differences at the sub-dimensions, the unemployment anxiety sub-dimensions were determined. It was determined that there is a difference in the unemployment anxiety dimensions according to the demographic characteristics of area, departments, gender, settlement areas and overall grade average.

Keywords: Unemployment, Young Unemployment, Unemployment Anxiety, University Students.

\section{Giriş}

İş hayatına girme yaşına gelmiş, iş bulma istek ve arzusunda olmasına rağmen iş bulamamış kişiler ile mevcut işini kaybeden ve yeni bir iş arayışında bulunanlar işsiz olarak tanımlanır İşsizlik, kişiyi umutsuzluk, çaresizlik, gibi duygulara sürüklemektedir. Bir işe sahip olmak, çalışma karşılığ Temel ihtiyaçlardan mahrum kalındığında, ihtiyaçlar engellendiğinde veya geciktiğinde hayal kırıklı̆̆ı, kaygı, çatışma ortaya çıkacaktır (Aytaç ve Keser, 2002).

Gelişmekte olan ülkelerde gençlerin karşılaştı̆̆ problemlerin ilk sırasında ilk işe başlama süreci gelmektedir (Murat, 1991). İşgücü piyasasına iyi bir başlangıç yapan gençler sonraki yıllarında daha az işsizlik riskiyle karşılaşmaktadır (Savcı, 2007: 89). İşsizlik her yaşta kötü olmakla birlikte, bir kişinin profesyonel yaşamının erken dönemlerinde özellikle daha ağır bir süreç olarak yaşanabilmektedir. Artan akademik literatür, erken işsizliğin bireyin pek çok yönden maaşının olmaması, zihinsel ve fiziksel sağlık, aileleri (artan mali yük ve işsizlik durumuyla başa çıkma zorluğu), ekonomik kaynakların ve tüm ülkenin sosyal istikrar, suçluluk ve vergi gelirlerinin kaybı tehdidi yönünden etkilendiğini göstermektedir. Uzun süren genç işsizlik krizinden kaynaklanan ekonomik ve sosyal maliyetler, ekonomilerin büyüme potansiyelinin zayıflamasına neden olmaktadır (Vogel, 2015: 2).

Gençlerin gelecekten beklentilerinin sorulduğu bir araştırmada ilk sırayı iyi bir iş sahibi ve toplum tarafından saygı duyulan bir birey olma almıştır. İkinci sırada huzurlu bir yaşam sürme ve üçüncü sırada zengin olma beklentisi olmuştur (Yavuzer vd., 2005: 95). Gençlerin iş bulamama kaygısı gençlerde bir ümitsizlik oluşturmakta, ümitsizlikle birlikte hedeflerden vazgeçilmesi ile yanlış tercihler yapılmasına yol açabilmektedir (Koçak ve Çepni, 2017).

2015 yılı Uluslararası Antalya Üniversitesi TNS ortaklığının Türkiye genelinde 18 ilde 18 yaş ve üzeri 1512 kişiyle gerçekleştirdiği araştırmaya göre araştırmaya katılan 18-24 yaş grubu gençlerde en büyük birinci sorun \%50,1 ile işsizlik, ikinci sorun eğitim ve üçüncü sorun ekonomi olarak sıralamada yer almıştır. Gençler arasında işsizliğin en önemli nedeni iş alanının olmaması $\% 29,9$, asgari ücretin yetersiz olması/maaşın yetersiz olması $\% 13$, iş beğenmeme \%9,2, eğitim \%7,9 ilk sıralarda belirtilen hususlar olmuştur (Hürriyet, 2016).

Year 4/ 2020, Volume-4, Issue-3 | www.ispecjournal.org 
Dünyada 15-29 yaş gençler sınırlı iş becerileri, iş deneyimi ve pazarlık gücüne sahip olduklarından, bulabildikleri fırsatlar genellikle giriş seviyesi işlerdir. Dünyada yetişkinlerden üç kat daha yüksek bir genç işsizlik oranı vardır (ILO, 2018). Türkiye'de 2019 yılı genç nüfusta istihdam oranı \%33,1 ve işsizlik oranı \%25,4 olarak gerçekleşmiştir (TÜİK, 2020). 15-34 yaş grubu içinde işsizlik oranı 20-24 yaş grubu için \%27,6 ve 25-34 yaş grubu için \%15,5'dir (TÜİK, 2019). Yaş ilerledikçe işsizlik oranında azalış olduğu söylenebilir.

Dünya genelinde genç işsizlik oranları yüksektir. Bu, üniversiteden mezun olduktan sonra iyi bir iş garantisi olmadığı anlamına gelmektedir. Birçok genç geleceği konusunda emin değildir. Winefield ve Tiggemann'a (1989) göre, beklentilerin hayal kırıklığıyla sonuçlanması ve ekonomik güç kazanamamak gençler için çok önemli sorun olabilmektedir. Bireyin işsizlik deneyimi yaşaması mali sıkıntı, işsizlik kaygısı, psikolojik sıkıntı, fiziksel hastalık, aile çatışması ve yetersizlik duygularına yol açabilmektedir (Wanberg ve vd., 1999).

ABD Federal Rezerv Bankası'na (FED) göre, üniversite derecesi olan 22 ila 27 yaşları arasında tanımlanan üniversite mezunlarının işsiz kalma olasılığı genel işçilere göre daha yüksektir. İstatistikler, üniversite mezunları için işsizlik oranının istikrarlı bir şekilde arttığını, diğer tüm çalışanların genel işsizlik oranının son 10 yılda hızla düşmekte olduğunu göstermektedir (Kelly, 2019).

Türkiye'de bireylerin eğitim durumuna göre işsizlik oranları farklılıklar göstermektedir. Tablo 1'den en yüksek genç işsizlik oranı tüm yıllar için yükseköğretim mezunlarında görülmektedir. Eğitim düzeylerine bakıldığında 2014-2019 yılları için en yüksek işsizlik oranları yükseköğretim mezunlarında olmuştur. Yı1lar itibariyle yükseköğretim mezunları için en yüksek işsizlik oranı 2019 yılında olmuştur.

Tablo 1. Eğitim durumu ve yıllara göre 2014-2019 yılları arası işsizlik oranları (15-24 yaş grubu) (\%)

\begin{tabular}{|c|c|c|c|c|c|c|}
\hline & 2014 & 2015 & 2016 & 2017 & 2018 & 2019 \\
\hline Okuma Yazma Bilmeyen & 12,1 & 7,9 & 13,4 & 12,1 & 12 & 20,9 \\
\hline $\begin{array}{lllll}\text { Okuma Yazma } & \text { Bilen } & \text { Fakat } & \text { Bir } & \text { Okul } \\
\text { Bitirmeyen } & & & & \end{array}$ & 15 & 14,1 & 15 & 16,1 & 18,7 & 17,5 \\
\hline İlkokul & 16 & 16,3 & 16,5 & 14,1 & 14,7 & 22,6 \\
\hline İlköğretim & 14,8 & 15,6 & 15,8 & 16,2 & 17 & 21,7 \\
\hline Ortaokul veya Dengi Meslek Ortaokul & 13,1 & 14 & 14,1 & 13,8 & 14,3 & 18,7 \\
\hline Genel Lise & 20,4 & 22,2 & 22,8 & 24,4 & 23,5 & 28,9 \\
\hline Lise Dengi Mesleki Okulu & 19,3 & 18,1 & 21 & 21,8 & 21,3 & 27,4 \\
\hline Yüksek Öğretim & 28,3 & 29,5 & 30,8 & 34,4 & 30,6 & 35,6 \\
\hline
\end{tabular}

Kaynak: TÜİK (2020)

Year 4/ 2020, Volume-4, Issue-3 | WwW.ispecjournal.org 
Tüm ekonomilerde vasıf taleplerinin yükselmesi, yetişkinlerden daha az vasıf ve deneyime sahip olan gençleri işsizlik riskine karşı daha savunmasız hale getirmektedir. İstenilen niteliklerden yoksun olarak çalışma hayatına başlayan gençler genellikle uzun dönemli işsizlik riskiyle karşılaşmaktadır (Günoğdu, 2005: 106). Devam eden yüksek düzeyde genç işsizliği, birçok nedenden dolayı önemli bir sosyal sorun olarak algılanmaktadır. Ergenlik döneminde işsizliğin sağlıklı psikososyal gelişimi geciktirebileceğini varsaymak için yaşam boyu gelişim teorisine dayanan teorik nedenler vardır (Erikson, 1959, Aktaran: Winefield, 1997).

Çoğu genç için, okuldan mezun olmak ve işe başlamak yetişkinlik statüsüne veya yetişkin sosyal kimliğine geçiştir (Patterson, 1997). İstihdam sağlanamaması genç profesyonellerin geleceği konusunda kötümser olmalarına neden olabilmekte ve Prause ve Dooley'in (1995) de vurguladığı gibi, artan işsizlik oranlarından kaynaklanan hastalığın sosyal problemleri de içerebileceği görülebilmektedir (Ersoy-Kart ve Erdost, 2008).

1980'lerin başından bu yana, genç işsizliğinin sağlık sonuçlarıyla ilgili artan sayıda makale yayınlanmıştır. Farklı çalışmalarda gösterildiği üzere sağlık sorunları en fazla olan gençler ilk kez işsiz kalanlardır. Psikolojik/psikiyatrik bozukluklar, araştırmaların çoğunun yönlendirildiği alandır. Dünyanın farklı yerlerinden, her iki cinsiyetten ve farklı etnik kökenlerden gelen gençlerin ve yetişkinlerin çalışmalarına göre işsizlik ve psikolojik bozukluklar arasında tutarlı bir ilişki olduğu gösterilmiştir (Hammarström, 1994).

Gençlerde işsizlik ile kötü ruh sağlı̆̆ı/psikolojik iyi olma arasında bir ilişki olduğu bilinmektedir. Tipik olarak, örneğin, işsiz olanlar daha düşük benlik saygısı gösterirler, işsizlik kaygısı yaşarlar ve iş sahibi olanlardan daha duygusal olarak depresyona girerler. $\mathrm{Bu}$ ilişkiyi açıklamak için iki açıklama önerilmiştir. Birincisi, işsizliğin psikolojik refahta düşüşe neden olduğu ileri sürülmüştür. Bu hipotez "maruz kalma" (veya "sosyal nedensellik") hipotezi olarak bilinir. İkincisi, psikolojik iyi olma durumu düşük olan insanlara iş imkânı sunulma olasılığı daha düşüktür (ve/veya işten çıkarılma olasılığı daha yüksektir) (Winefield, 1997).

Bireyin tedirginlik ya da endişe duyması yaklaşmakta olduğunu sandığı bir tehlike kaynaklı olduğunda hissettiği kaygı duygusu olmaktadır. İşsizlik kaygısı, bireyi pasifliğe itmekte, depresyona ortam hazırlamakta, bireyde karamsarlık, çaresizlik, yaşama küskünlük gibi duygulara yol açmakta dolayısıyla bireyin saygınlığını yitirmesine neden olabilmektedir (Dursun ve Aytaç, 2009).

İş bulamıyor olma nedeniyle genç birey bunalıma sürüklenebilmekte, çaresiz ve umutsuz hissedebilmektedir. Dolayısıyla genç geleceğinden de ümitsiz ve kaygılı olmaktadır (Önocak, 2008). Türkiye'de üniversitede eğitim gören gençlerin mezun olduktan sonra iş bulamama kaygısına yaşamalarına neden olan etkenler eğitimli işgücü istihdam imkânlarının düşük olması ile eğitimli işgücü işsizlik oranlarının yüksek olmasıdır (Özkan, 2013: 48). 
Ülkemiz ve dünyada nüfus artışı ve eğitim düzeyinin yükselmesiyle işsizlik oranları üniversite mezunu bireylerde artı̧̧ göstermektedir (Koçak ve Çepni, 2017). Genç üniversite mezunları işsizlik sorunundan daha fazla etkilenmektedir. Konuyla ilgili yapılan çalışmalarda yaş ortalaması 18-25 olan üniversite öğrencilerinin kaygı belirtilerinin çok yüksek olduğu gözlenmiştir.

Üniversite öğrencileri ile yapılan çeşitli çalışmalar, kaygı, depresyon, sinirlilik, öfke, obsesif kompulsif özellikler, kişiler arası ilişkilerde huzursuzluk gibi etkisi güçlü olan sorunların ortaya çıktığını göstermektedir (Ateş, 2019). Üniversite eğitiminin son yıllarına doğru öğrencilerin işsizlik kaygısında artışlar olmaktadır. Üniversite son sınıf öğrencilerinin kaygı ve umutsuzluğunu etkilediği varsayılan en önemli etmenler gelecek kaygısı ve iş bulamama endişesidir. Türkiye'de yüksek eğitimli işgücünün istihdam oranlarının düşük olması nedeniyle gençlerin mezuniyet sonrası iş bulamama kaygısı çok yüksek olmaktadır. Üniversite öğrencileri ile iş bulamama kaygısı arasında ilişki olduğu belirlenmiştir (Akgün, 2019).

Bu çalışmada, çalı̧̧ma kapsamına alınan üniversite öğrencilerinin demografik özelliklerine göre işsizlik kaygısı açısından farklılıkların araştırılması amaçlanmıştır. Çalışmanın amacı doğrultusunda bir uygulama çalışması yapılmasına karar verilmiştir. Uygulama çalışması Nevşehir Hacı Bektaş Veli Üniversitesi Fen Edebiyat Fakültesi son sınıf öğrencileri arasından tabakalı örnekleme yöntemiyle seçilen 180 öğrenci üzerinden yürütülmüştür. Verilerin derlenmesi yüz yüze anket yöntemiyle gerçekleştirilmiştir. Örneklemden derlenen veride değişkenlerin sınıflanmasında çok değişkenli istatistiksel analizlerden faktör analizi uygulanmıştır. Verilerin analizinde çalı̧̧ma hipotezlerinin sinanmasında parametrik testlerden tek yönlü varyans analizi ve bağımsız örneklemler $t$ testi kullanılmışıtr. İşsizlik kaygısı alt boyutları belirlenerek alt boyutlarında farklılıkların değerlendirmeleri yapılmaya çalışılmıştır.

\section{2. İşsizlik Kaygısının Öğrencilerin Demografik Özelliklerine Göre Farklılıklarının İncelenmesine İlişkin Uygulama}

\section{1 Çalışmanın Amacı ve Hipotezleri}

Çalışmanın amacı demografik farklılıklara göre üniversite son öğrencilerinin işsizlik kaygıları arasında farklılık olup olmadığını araştırmaktır. Araştırmanın amacı doğrultusunda araştırma hipotezleri aşağıdaki gibi belirlenmiştir.

$\mathrm{H}_{1,1}$ : Fen ile sosyal bilimler alanı öğrenciler arasında işsizlik kaygısı bakımından farklılık vardir.

$\mathrm{H}_{1,2}$ : Öğrencilerin okuduğu bölümlere göre işsizlik kaygısı bakımından farklılık vardır.

$\mathrm{H}_{1,3}$ : Kadın ile erkek öğrenciler arasında işsizlik kaygısı bakımından farklılık vardır.

$\mathrm{H}_{1,4}$ : Ailede ticaretle uğraşan olma durumuna göre işsizlik kaygısı bakımından farklılık vardır.

Year 4/ 2020, Volume-4, Issue-3 | WwW.ispecjournal.org 
$\mathrm{H}_{1,5}$ : Yerleşim yerlerine göre işsizlik kaygısı bakımından farklılık vardır.

$\mathrm{H}_{1,6}$ : Öğrenci genel not ortalamasına göre işsizlik kaygısı bakımından farklılık vardır.

$\mathrm{H}_{1,7}$ : İş deneyimi olması durumuna göre işsizlik kaygısı bakımından farklılık vardır.

$\mathrm{H}_{1,8}$ : Anne eğitim durumuna göre işsizlik kaygısı bakımından farklılık vardır.

$\mathrm{H}_{1,9}$ : Baba eğitim durumuna göre işsizlik kaygısı bakımından farklılık vardır.

$\mathrm{H}_{1,10}$ : Aile gelirine göre işsizlik kaygııı bakımından farklılık vardır.

\section{2. Çalışmanın Kitlesi ve Örneklemi}

Araştırma hedef kitlesini Nevşehir Hacı Bektaş Veli Üniversitesi Fen Edebiyat Fakültesi 255 sayıdaki son sınıf öğrencileri oluşturmuştur. Araştırmanın örneklemini belirlemek amacıyla fen ve sosyal bilimler öğrencileri arasından olasılıksal örnekleme yöntemlerinden tabakalı örnekleme yöntemiyle örneklem birimleri seçimi yapılmıştır. Tabaka çaplarına orantılı olarak fen bilimleri bölümlerinden 41 ve sosyal bilimler bölümlerinden 139 öğrenci, toplam 180 öğrenci örnekleme seçilmiş̧ir.

\section{3. Çalışmanın ölçeği}

Öğrencilerin işsizlik kaygısını belirlemek için Tayfun ve Korkmaz'ın (2016) literatür doğrultusunda belirlediği psikometrik ifadelerinden yararlanılan Balkaya (2017) çalışması ölçeği kullanılmıştır. Ölçek ifadeleri 1: Hiç katılmıyorum ile 5: Kesinlikle katıllyorum arasında değişen 5'li likert tipi yapısında hazırlanmıştır. Ankette demografik özellikleri içeren ifadelere yer verilmiştir. Araştırmada veri toplama aracı olarak yüz yüze anket yöntemi kullanılmıştır.

\section{4. Çalışmanın yöntemi}

Verilerin normal dağılım incelemesi Kolmogrov-Smirnov testi ve tanımlayıcı istatistiklerden çarpıklık basıklık katsayılarına dayalı belirlenmiştir. Araştırma değişkenleri işsizlik kaygısı ifadeleri arasında ilişkiler olması durumunu giderilmesi ve değişkenlerin sınıflanması keşfedici faktör analiziyle yapılmıştır. Çalışmanın hipotezlerinin sınamasında parametrik testlerden tek yönlü varyans analizi ve bağımsız örneklemler $t$ testi kullanılmıştır. Verilerin analizinde kullanılan istatistiksel yazılım IBM SPSS Statistics 24'tür. 


\subsection{Bulgular}

\subsection{1. Öğrencilerin Demografik Özellikleri Bulguları}

Araştırmaya Fen Edebiyat Fakültesinde okuyan 180 son sınıf öğrencisi katılmıştır. Öğrencilerin \%22,8'i fen bilimleri ve \%77,2'si sosyal bilimler bölümleri öğrencileridir. Öğrencilerin 67,8'i kadın ve 32,2‘s1 erkektir. Yerleşim yerine göre \%50,6 ile şehir merkezinde yaşayanlar oluşturmaktadır. Ankete katıların \%75,6'sıyla büyük kesiminde ailesinde ticaretle uğraşan yoktur. Ankete katılanların annelerinin eğitim durumunu \%61,7 ile çoğunluğunu ilköğretim mezunu yine ankete katılanların babalarının eğitim durumunu \%48,9'u ile ilköğretim mezunları oluşturmaktadır.

Tablo 2. Öğrencilerin demografik özellikleri

\begin{tabular}{|c|c|c|c|c|c|}
\hline Alan & Frekans & Yüzde & Ailede Ticaretle Uğraşan & Frekans & Yüzde \\
\hline Fen & 41 & 22,8 & Var & 44 & 24,4 \\
\hline Sosyal & 139 & 77,2 & Yok & 136 & 75,6 \\
\hline Cinsiyet & Frekans & Yüzde & Yerleşim yeri & Frekans & Yüzde \\
\hline Kadın & 122 & 67,8 & Köy & 26 & 14,4 \\
\hline Erkek & 58 & 32,2 & Kasaba-ilçe & 63 & 35,0 \\
\hline Anne-Eğitimi & Frekans & Yüzde & Şehir merkezi & 91 & 50,6 \\
\hline Okur-yazar değil & 23 & 12.8 & İş Deneyimi & Frekans & Yüzde \\
\hline İlköğretim & 111 & 61.7 & Yok & 85 & 47,2 \\
\hline Lise & 38 & 21,1 & $1-3$ ay & 26 & 14,4 \\
\hline Üniversite & 8 & 4,4 & $4-6$ ay & 20 & 11,1 \\
\hline Baba Eğitimi & Frekans & Yüzde & $7-9$ ay & 15 & 8,3 \\
\hline Okur-yazar değil & 6 & 3,3 & 9 ay üzeri & 34 & 18,9 \\
\hline İlköğretim & 88 & 48,9 & Bölüm & Frekans & Yüzde \\
\hline Lise & 65 & 36,1 & Matematik & 13 & 7,2 \\
\hline Üniversite & 21 & 11,7 & Moleküler Biyoloji ve Genetik & 28 & 15,6 \\
\hline Aile Aylık Gelir & Frekans & Yüzde & Arkeoloji & 37 & 20,6 \\
\hline $500-1500$ & 28 & 15,6 & Sosyoloji & 28 & 15,6 \\
\hline $1501-2500$ & 53 & 29,4 & Tarih & 37 & 20,6 \\
\hline $2501-3500$ & 46 & 25,6 & Türk Dili ve Edebiyatı & 37 & 20,6 \\
\hline $3501-4500$ & 33 & 18,3 & & & \\
\hline 4501 ve üzeri & 20 & 11,1 & & & \\
\hline
\end{tabular}

Öğrencilerin \%29,4 ile çoğunluğu 1501-2500 arasında aylık ortalama aile gelirine sahiptir. Öğrencilerin \%47,2'sinin iş deneyimi yoktur. \%20,6's1 Arkeoloji, \%20,6's1 Türk Dili ve 
\%20,6's1 Tarih, \%15,6's1 Moleküler Biyoloji ve Genetik, \%15,6's1 Sosyoloji bölümü ve $\% 7,2$ 'si Matematik bölümü öğrencileridir.

Tablo 3'te ortanca katılım düzeylerinin 3: Karasızım ile 4: Katıliyorum olduğu Tablo 3'ten görülmektedir. Ancak, "Ailemden yakın gelecekte bir iş sahibi olmam için baskı görüyorum” ifadesi ortancası 2: Katılmıyorum olduğu görülmektedir. Yüzde dağılımlarına bakıldığında işsizlik kaygısı ifadelerinin çoğunluğuna "Katılıyorum" ile "kesinlikle katılıyorum" yanıtı verilmiştir. Ancak, yüzde dağılımlarının yüksek olduğu "Hiç katılmıyorum” ile "Katılmıyorum" yanıtının verildiği ifadeler "Ailemden yakın gelecekte bir iş sahibi olmam için baskı görüyorum.”; "Yakın çevremdeki insanların üniversiteyi bitirdikten sonra işsiz kalmaları neden okuduğumu sorgulatmakta, nasılsa iş yok düşüncesiyle okulu birakmayı düşündürmektedir."; "Kendimi nitelikli bir işgücü olarak göremiyorum." ve "Kendimi gelecekte çalışmak istediğim alanla ilgili bilgi ve beceri sahibi olarak göremiyorum." olmuştur.

Tüm ifadelerde en yüksek yüzde dağılımı "Katılıyorum" ile "kesinlikle katılıyorum" yanıtına karşılık gelen \%77,2 ile "Yakın gelecekte içinde bulunacağım işgücü piyasasında durumum belirsizdir." ifadesine aittir. İkinci sırada en yüksek yüzde dağılımı \%73,9 ile "Türkiye'de mezun olacağım bölümle ilgili iş olanakları kısıtlıdır." ifadesidir. Üçüncü sırada en yüksek yüzde dağılımı \%70 ile "Okuduğum bölümle ilgili iş olanaklarının yeterli olduğunu düşünmüyorum.” ifadesidir.

Tablo 3. İşsizlik kaygısı ifadeleri ortanca ve yüzde dağılımı

\begin{tabular}{|c|c|c|c|}
\hline M & $\begin{array}{l}1-2 \text { birikimli } \\
(\%)\end{array}$ & $\begin{array}{l}3 \\
(\%)\end{array}$ & $\begin{array}{l}4-5 \text { birikimli } \\
(\%)\end{array}$ \\
\hline $\begin{array}{l}\text { 1. Yakın gelecekte içinde bulunacağım işgücü piyasasında durumum } 4 \\
\text { belirsizdir. }\end{array}$ & 7,3 & 15,6 & 77,2 \\
\hline \begin{tabular}{|l|l|} 
2. Hayattan beklediğim şeylere kavuşabileceğimi düşünmüyorum. & 3 \\
\end{tabular} & 35,5 & 27,8 & 36,7 \\
\hline \begin{tabular}{|l|l|} 
3. Eğitimim sonrası hayatımın daha sıkıntılı olacağını düşünüyorum. & 4 \\
\end{tabular} & 23,9 & 25 & 51,1 \\
\hline $\begin{array}{l}\text { 4. Gelecekteki iş hayatımın ve meslek sahibi olmanın oldukça belirsiz bir } 4 \\
\text { durum olduğunu düşünüyorum. }\end{array}$ & 16,6 & 25 & 58,3 \\
\hline \begin{tabular}{|l|l|l|} 
5. Şimdiki hayatıma kıyasla gelecekte daha mutlu olacağımı düşünmüyorum. & 3 \\
\end{tabular} & 32,3 & 33,9 & 33,9 \\
\hline $\begin{array}{l}\text { 6. İşsiz kalırsam çevreme karşı itibarımı yitireceğimden ve gittikçe içime } 3 \\
\text { kapanmaya başlayacağımdan endişe ediyorum. }\end{array}$ & 32,2 & 22,8 & 45 \\
\hline $\begin{array}{l}\text { 7. Bu gidişle meslek sahibi olabilmem için yeni bir bölüm daha okumam } 3 \\
\text { gerekebilir. }\end{array}$ & 27,2 & 28,3 & 44,4 \\
\hline 8. Ailemden yakın gelecekte bir iş sahibi olmam için baskı görüyorum. & 54,5 & 15,6 & 30 \\
\hline $\begin{array}{l}\text { 9. Mezuniyetimden sonraki } 3 \text { yıl içinde iş bulamamam benim için bir4 } \\
\text { travmadır. }\end{array}$ & 22,3 & 20 & 57,8 \\
\hline $\begin{array}{l}\text { 10. Yakın çevremdeki insanların üniversiteyi bitirdikten sonra işsiz kalmaları } 3 \\
\text { neden okuduğumu sorgulatmakta, nasılsa iş yok düşüncesiyle okulu bırakmayı } \\
\text { düşündürmektedir. }\end{array}$ & 46,1 & 16,7 & 37,2 \\
\hline 11. Yakın arkadaşlarımın yaşadığı işsizlik kaygısı beni de etkilemektedir. & 16,2 & 20 & 63,9 \\
\hline $\begin{array}{l}\text { 12. Aldığım eğitimle ilişkili mesleğin, gelir olarak ihtiyaçlarımı } 3 \\
\text { karşılamayacağını düşünüyorum. }\end{array}$ & 35 & 28,9 & 36,1 \\
\hline 13. İyi bir işim olması için sanırım lisansüstü eğitim almam gerekecek. & 13,9 & 23,3 & 62,8 \\
\hline
\end{tabular}

Year 4/ 2020, Volume-4, Issue-3 | wWw.ispecjournal.org 


\begin{tabular}{|c|c|c|c|}
\hline $\begin{array}{l}\text { 14. Aldığım eğitim gelecekte sahip olabileceğim meslekler için yetersiz } 3 \\
\text { kalabilir. }\end{array}$ & 26,7 & 29,4 & 43,9 \\
\hline $\begin{array}{l}\text { 15. Sahip olduğum nitelikler ve almakta olduğum eğitim iyi yerlere } 3 \\
\text { gelebilmem için yeterli değildir. }\end{array}$ & 28,3 & 27,2 & 44,4 \\
\hline 16. Kendimi nitelikli bir işgücü olarak göremiyorum. & 46,7 & 27,8 & 25,6 \\
\hline $\begin{array}{l}\text { 17. Kendimi gelecekte çalışmak istediğim alanla ilgili bilgi ve beceri sahibi } 3 \\
\text { olarak göremiyorum. }\end{array}$ & 42,2 & 25,6 & 32,3 \\
\hline $\begin{array}{l}\text { 18. Ülkemizde istihdam olanaklarının eğitimli gençler için az olması iş4 } 4 \\
\text { bulamayacağımı düşündürmektedir. }\end{array}$ & 13,4 & 22,2 & 64,4 \\
\hline \begin{tabular}{|l|l} 
19. Türkiye'de mezun olacağım bölümle ilgili iş olanakları kısıtlıdır. & 4
\end{tabular} & 8,3 & 17,8 & 73,9 \\
\hline $\begin{array}{l}\text { 20. Yakın çevremin mezun olduktan sonra iş bulamama durumları bana da } 4 \\
\text { gelecekte iş bulamayacağımı düşündürmektedir. }\end{array}$ & 18,3 & 24,4 & 57,2 \\
\hline $\begin{array}{l}\text { 21. KPSS, YDS, ALES gibi sınavlara girmem veya Formasyon almam bir işe } 4 \\
\text { girebilmemin ya da işsizlik hayatımın ilk adımıdır. }\end{array}$ & 18,8 & 21,7 & 59,4 \\
\hline 22. Çalışmak istediğim meslekte işgücü ihtiyacının azalması beni korkutuyor. 4 & 12,2 & 22,8 & 65 \\
\hline $\begin{array}{l}\text { 23. Yeni mezun arkadaşlarımın işsiz kalması bana da işsiz kalabileceğimi } 4 \\
\text { düşündürmektedir. }\end{array}$ & 16,1 & 18,9 & 65 \\
\hline $\begin{array}{l}\text { 24. Okuduğum bölümle } \text { ilgili } \text { iş olanaklarının yeterli olduğunu4 } 4 \\
\text { düşünmüyorum. }\end{array}$ & 11,1 & 18,9 & 70 \\
\hline \begin{tabular}{|l|l} 
25. İlerde çalışmak istediğim sektörün gittikçe daraldığını görüyorum. & 4
\end{tabular} & 17,8 & 19,4 & 62,8 \\
\hline
\end{tabular}

(Tabloda birinci satırı M: Ortanca ve 1-2 Birikimli (\%): 1:Hiç katılmıyorum ile 2: Katılmıyorum, 3(\%): Kararsızım ile 4-5 birikimli: 4: Katılıyorum ile 5: Kesinlikle Katılıyorum yanıtını verenlerin yüzdesini ifade etmektedir.)

\subsubsection{Analiz Bulguları}

Parametrik testlerin ve faktör analizinin uygulanabilmesi için verilerin normal dağılımlı olması istenir. Çalışmada normal dağılım varsayımının sağlanıp sağlanmadığı KolmogrovSmirnov testi ve tanımlayıcı istatistiklerden çarpıklık ve basıklık katsayısı incelemeleriyle belirlenmeye çalışılmıştır. Normal dağılım incelemesi Kolmogrov Smirnov testiyle araştırılmış ve verilerin normal dağılımlı olmadığı belirlenmiştir. Ancak, ayrıca çarpıklık basıklık katsayıları incelenmiştir. Yüksek düzeyde çarpıklık gösteren kitlelerden örnekleme yapmak tahminlerin dağılımının normallik varsayımlarının sağlanmamasına neden olur (Kish, 1965). Normal dağılım incelemelerinin çarpıklık ölçümüne daha duyarlı olduğu belirlenmiştir. Çalışmada çarpıklık katsayıları için hesaplanan $\mathrm{z}$ istatistik değerleri $\alpha=0,01$ düzeyinde $-z_{\alpha / 2}=-2,57 \leq z \leq z_{\alpha / 2}=2,57$ aralığ1 içinde değer alması durumunda verilerin normal dağılımlı olduğu kabul edilir. Normal dağılıma uymayan ifadeler için normallik dönüşümlerinden kare alma dönüşümü uygulanmıştır. Böylece veri normal dağılım varsayımını sağlamıştır. Böylece çalışmada parametrik testler uygulanabilmiştir.

Tüm sorular için güvenilirlik analizi sonucu Cronbach $\alpha$ değeri 0,865 olarak belirlenmiştir. $\alpha$ değeri $0,80 \leq \alpha<1,00$ aralığında olduğu için ölçek yüksek derecede güvenilirdir yorumu yapılır (Özdamar, 1999: 522). Çalışmada işsizlik kaygısı ölçeği verilerine uygulanan keşfedici 
faktör analizi sonuçları ve analiz sonucu oluşan her bir faktör için güvenilirlik analizi Cronbach $\alpha$ değerleri Tablo 4'te sunulmaktadır.

Tablo 4. İşsizlik kaygısı ölçeği faktör analizi bulguları

\begin{tabular}{|c|c|c|c|c|}
\hline & Faktör yükü & Özdeğer & $\begin{array}{l}\text { Varyans } \\
(\%)\end{array}$ & Cronbach $\alpha$ \\
\hline İSTİHDAMDAKİ ZORLUKLAR & & 7,107 & 32,306 & 0,865 \\
\hline \multicolumn{5}{|l|}{$\begin{array}{l}\text { Çalışmak istediğim meslekte işgücü ihtiyacının azalması beni } 0,792 \\
\text { korkutuyor. }\end{array}$} \\
\hline \multicolumn{5}{|l|}{$\begin{array}{l}\text { Yeni mezun arkadaşlarımın işsiz kalması bana da işsiz } 0,775 \\
\text { kalabileceğimi düşündürmektedir. }\end{array}$} \\
\hline \multicolumn{5}{|l|}{$\begin{array}{l}\text { Okuduğum bölümle ilgili iş olanaklarının yeterli olduğunu 0,746 } \\
\text { düşünmüyorum. }\end{array}$} \\
\hline \multicolumn{5}{|l|}{\begin{tabular}{|l|l|l|} 
Türkiye'de mezun olacağım bölümle ilgili iş olanakları kısıtlıdır. & 0,723 \\
\end{tabular}} \\
\hline \multicolumn{5}{|l|}{\begin{tabular}{|llll} 
Illerde çalışmak istediğim sektörün gittikçe daraldığını 0,715 \\
görüyorum.
\end{tabular}} \\
\hline \multicolumn{5}{|l|}{$\begin{array}{l}\text { KPSS, YDS, ALES gibi sınavlara girmem veya Formasyon 0,676 } \\
\text { almam bir işe girebilmemin ya da işsizlik hayatımın ilk adımıdır. }\end{array}$} \\
\hline \multicolumn{5}{|l|}{$\begin{array}{l}\text { Ülkemizde istihdam olanaklarının eğitimli gençler için az olması 0,640 } \\
\text { iş bulamayacağımı düşündürmektedir. }\end{array}$} \\
\hline \multicolumn{5}{|l|}{$\begin{array}{l}\text { Yakın çevremin mezun olduktan sonra iş bulamama durumları 0,579 } \\
\text { bana da gelecekte iş bulamayacağımı düşündürmektedir. }\end{array}$} \\
\hline ÇEVRESEL VE SOSYAL BASKI & & 2,951 & 13,414 & 0,631 \\
\hline \multicolumn{5}{|l|}{$\begin{array}{l}\begin{array}{l}\text { Yakın arkadaşlarımın } \\
\text { etkilemektedir. }\end{array} \\
\text { thaşadığı işsizlik kaygısı beni de } 0,501 \\
\end{array}$} \\
\hline \multicolumn{5}{|l|}{$\begin{array}{l}\begin{array}{l}\text { Ailemden yakın gelecekte bir iş sahibi olmam için baskı0,771 } \\
\text { görüyorum. }\end{array} \\
\end{array}$} \\
\hline \multicolumn{5}{|l|}{$\begin{array}{l}\text { Yakın çevremdeki insanların üniversiteyi bitirdikten sonra işsiz } 0,707 \\
\text { kalmaları neden okuduğumu sorgulatmakta, nasılsa iş yok } \\
\text { düşüncesiyle okulu bırakmayı düşündürmektedir. }\end{array}$} \\
\hline \multicolumn{5}{|l|}{$\begin{array}{l}\text { Bu gidişle meslek sahibi olabilmem için yeni bir bölüm daha0,646 } \\
\text { okumam gerekebilir. }\end{array}$} \\
\hline \multicolumn{5}{|l|}{$\begin{array}{l}\text { Mezuniyetimden sonraki } 3 \text { yıl içinde iş bulamamam benim için } 0,596 \\
\text { bir travmadır. }\end{array}$} \\
\hline \multicolumn{5}{|l|}{$\begin{array}{l}\text { İşsiz kalırsam çevreme karşı itibarımı yitireceğimden ve gittikçe } 0,595 \\
\text { içime kapanmaya başlayacağımdan endişe ediyorum. }\end{array}$} \\
\hline NİTELİKSEL OLARAK BİLGİ VE BECERİ EKSİKLİĞİ & & 1,724 & 7,835 & 0,802 \\
\hline Kendimi nitelikli bir işgücü olarak göremiyorum. & 0,831 & & & \\
\hline \multicolumn{5}{|l|}{$\begin{array}{l}\text { Kendimi gelecekte çalışmak istediğim alanla ilgili bilgi ve beceri } 0,797 \\
\text { sahibi olarak göremiyorum. }\end{array}$} \\
\hline \multicolumn{5}{|l|}{$\begin{array}{l}\text { Sahip olduğum nitelikler ve almakta olduğum eğitim iyi yerlere } 0,784 \\
\text { gelebilmem için yeterli değildir. }\end{array}$} \\
\hline \multicolumn{5}{|l|}{$\begin{array}{l}\text { Aldığım eğitim gelecekte sahip olabileceğim meslekler için } 0,652 \\
\text { yetersiz kalabilir. }\end{array}$} \\
\hline KİŞISEL KARAMSARLIK VE ÖZGÜVEN EKSİKLİĞİ & & 1,351 & 6,139 & 0,601 \\
\hline $\begin{array}{l}\text { Eğitimim sonrası hayatımın daha } \text { sıkıntılı olacağını } \\
\text { düşünüyorum. }\end{array}$ & 0,765 & & & \\
\hline
\end{tabular}




\begin{tabular}{|l|l|l|l|}
\hline $\begin{array}{l}\text { Yakın gelecekte içinde bulunacağım işgücü piyasasında } 0,671 \\
\text { durumum belirsizdir. }\end{array}$ & & \\
\hline $\begin{array}{l}\text { Gelecekteki iş hayatımın ve meslek sahibi olmanın oldukça } 0,643 \\
\text { belirsiz bir durum olduğunu düşünüyorum. }\end{array}$ & & \\
\hline Hayattan beklediğim şeylere kavuşabileceğimi düşünmüyorum. 0,638 & & \\
\hline $\begin{array}{l}\text { Toplam varyans }=59,695 \\
\text { KMO }=0,881 \\
\text { Bartlett Küresellik testi ki kare değeri }=1780,038 \mathrm{p}=0,00\end{array}$ & \\
\hline
\end{tabular}

İşsizlik kaygısı ölçeği için özdeğeri 1 üzerinde ve faktör yükü 0,50 üzeri olan 4 faktör vardır. $\mathrm{KMO}=0,881$ için 0,80'lerde değerli yorumu yapılabilir (Kaiser, 1974). Bartlett küresellik testi önem düzeyi $\mathrm{p}=0,00<0.05$ faktör analizinin veriler için faydalı, yaklaşık olarak çok değişkenli normal ve faktör analizi için kabul edilebilir olduğu yorumu yapılır. Temel bileşenler analizi uygulanarak varimax döndürme sonrası belirlenen 4 faktör toplam değişimin \%59,695'ini açıklamaktadır. Araştırmadaki ölçeklerin güvenilirlik katsayıları 0,60 ile 0,80 arasında olduğundan ölçek güvenilirdir (Kalaycı, 2006). Güvenilirlik katsayılarına bakıldığında faktörlerin güvenilir ölçek yapısına sahip olduğu söylenebilir.

Çalışmada faktör isimleri Balkaya (2017) çalışmasına dayalı belirlenmiştir. 1. faktör istihdamdaki zorluklar; 2. faktör çevresel ve sosyal bask1; 3. faktör niteliksel olarak bilgi ve beceri eksikliği ve 4. faktör kişisel karamsarlık ve özgüven eksikliği olarak adlandırılmıştır. Araştırma hipotezleri sırasıyla sınanacaktır.

Faktörlerin tanımlayıc istatistikleri ve histogram grafikleri incelenmiştir. Tablo 5'ten öğrencilerin istihdamdaki zorluklar boyutundaki ifadelere yüksek puanlar verdikleri belirlenmiştir. En düşük değer 3 ve en büyük değer 22,50 (dönüşümler sonucu kare alma işlemleri uygulandığı minimum maksimum değerler 1-5 arası değişmemektedir). İstihdamdaki zorluklar öğrencilerin en çok sıkıntı duydukları konu olmuştur. Niteliksel olarak bilgi ve beceri eksikliği ortalama değeri 2,635 ve öğrencilerin en düşük puan verdikleri faktör boyutu olmuştur.

Tablo 5. Araştırma faktörleri tanımlayıcı istatistikleri

\begin{tabular}{|l|l|l|l|l|}
\hline & Minimum & Maximum & Ortalama & Standart sapma \\
\hline İstihdamdaki zorluklar & 3,00 & 22,50 & 14,5701 & 5,24340 \\
\hline Çevresel ve sosyal baskı & 1,00 & 11,67 & 6,6602 & 2,57093 \\
\hline Niteliksel olarak bilgi ve beceri eksikliği & 1,00 & 5,00 & 2,635 & 0,87760 \\
\hline Kişisel karamsarlık ve özgüven eksikliği & 2,50 & 15,00 & 9,6611 & 3,44871 \\
\hline
\end{tabular}

Standart sapmaları incelendiğinde en az değişken cevapların en düşük standart sapma değerine sahip "Niteliksel olarak bilgi ve beceri eksikliği”" faktörü için olduğu Tablo 5'ten 
görülmektedir. Öğrencilerin bu faktör için benzer cevaplar verdiği söylenebilir. En değişken cevaplar en yüksek standart sapma değerli "İstihdamdaki zorluklar" faktörüne aittir.

\subsubsection{Fen ile Sosyal Bilimler Alanlarına göre İşsizlik Kaygısı Bakımından Farklıkların Belirlenmesi}

Farklılık olup olmadığı araştırması bağımsız örneklemler $\mathrm{t}$ testiyle araştırılacaktır. Öğrencilerin istihdamdaki zorluklar $(\mathrm{p}=0,00<\alpha=0,05)$, çevresel ve sosyal bask1 $(\mathrm{p}=0,045<\alpha=0,05)$, kişisel karamsarlık ve özgüven eksikliği $(\mathrm{p}=0,00<\alpha=0,05)$ için $\mathrm{H}_{1,1}$ hipotezi kabul edilmişsir.

Tablo 6. Fen ile sosyal bilimler alanlarına göre işsizlik kaygısı bakımından farklıkların bağımsız örneklemler $\mathrm{t}$ testi bulguları

\begin{tabular}{|c|c|c|c|c|c|}
\hline FAKTÖRLER & Alan & $n$ & Ortalama & $\mathrm{t}$ & $\mathrm{p}$ \\
\hline \multirow{2}{*}{ İstihdamdaki zorluklar } & Fen & 41 & 12,0854 & \multirow{2}{*}{$-3,564$} & \multirow{2}{*}{0,000} \\
\hline & Sosyal & 139 & 15,3031 & & \\
\hline \multirow{2}{*}{ Çevresel ve sosyal bask1 } & Fen & 41 & 5,9553 & \multirow{2}{*}{$-2,015$} & \multirow{2}{*}{0,045} \\
\hline & Sosyal & 139 & 6,8681 & & \\
\hline \multirow[b]{2}{*}{ Niteliksel olarak bilgi ve beceri eksikliği } & Fen & 41 & 3,0854 & \multirow{2}{*}{0.723} & \multirow[b]{2}{*}{0,472} \\
\hline & Sosyal & 139 & 2,9856 & & \\
\hline \multirow{2}{*}{ Kişisel karamsarlık ve özgüven eksikliği } & Fen & 41 & 7,4207 & \multirow{2}{*}{$-5,047$} & \multirow{2}{*}{0,000} \\
\hline & Sosyal & 139 & 10,3219 & & \\
\hline
\end{tabular}

Niteliksel olarak bilgi ve beceri eksikliği $(p=0,472>\alpha=0,05)$ için $H_{1,1}$ hipotezi kabul edilmemiştir. Farklılıkların belirlendiği faktörler için ortalamaların yorumu yapılır. Fen bilimleri bölümü öğrencilerinin ortalama yanıtları sosyal bilimler bölümü öğrencilerinin ortalama yanıtlarına kıyasla daha düşük puanlıdır. Bu faktörler için sosyal bilimler alan öğrencilerinin fen bilimleri alan öğrencilerine kıyasla daha yüksek kaygı duyduğu söylenebilir.

\subsubsection{2. Öğrencilerin Okuduğu Bölümlere Göre İşsizlik Kaygısı Bakımından Farklıkların Belirlenmesi}

Okunan bölümlere göre farklılık olup olmadığının araştırılması tek yönlü varyans analiziyle yapilacaktır. 
Tablo 7. Okunan bölüme göre işsizlik kaygısı boyutları varyans analizi bulguları

\begin{tabular}{|l|l|l|}
\hline & $\mathrm{F}$ & $\mathrm{p}$ \\
\hline İstihdamdaki zorluklar & 9,799 & 0,000 \\
\hline Çevresel ve sosyal bask1 & 2,642 & 0,025 \\
\hline Niteliksel olarak bilgi ve beceri eksikliği & 1,680 & 0,142 \\
\hline Özgüven eksikliği & 6,755 & 0,000 \\
\hline
\end{tabular}

Öğrencilerin okuduğu bölümlere göre istihdamdaki zorluklar $(p=0,00<\alpha=0,05)$, çevresel ve sosyal bask1 $(p=0,027<\alpha=0,05)$, özgüven eksikliği $(p=0,027<\alpha=0,05)$ için $\mathrm{H}_{1,2}$ hipotezi istatistiksel olarak anlamlı bulunmuştur. Anlamlı olduğu belirlenen çevresel ve sosyal baskı ile özgüven eksikliği için ortalamalar arası fark kontrolü testlerinden varyansları homojen belirlendiği için LSD testi uygulanmıştır.

Tablo 8. Okunan bölüme göre işsizlik kaygısı LSD testi bulguları

\begin{tabular}{|c|c|c|c|c|}
\hline & (I) BÖLÜM & (J) BÖLÜM & Ort, fark (I-J) & $\mathrm{p}$ \\
\hline \multirow[t]{7}{*}{ İstihdamdaki zorluklar } & Matematik & Tarih & $-5,64917^{*}$ & 0,000 \\
\hline & \multirow{3}{*}{$\begin{array}{l}\text { Moleküler } \\
\text { genetik }\end{array}$} & Sosyoloji & $-3,46429^{*}$ & 0,006 \\
\hline & & ve Tarih & $-7,00253^{*}$ & 0,000 \\
\hline & & Türk dili ve edebiyatı & $-3,35389^{*}$ & 0,005 \\
\hline & Arkeoloji & Sosyoloji & $-2,74216^{*}$ & 0,021 \\
\hline & Sosyoloji & Tarih & $-3,53825^{*}$ & 0,003 \\
\hline & Tarih & Türk dili ve edebiyatı & $3,64865^{*}$ & 0,001 \\
\hline \multirow[t]{4}{*}{ Çevresel ve sosyal baskı } & \multirow[t]{3}{*}{ Tarih } & Moleküler biy.ve gen, & $2,19337^{*}$ & 0,001 \\
\hline & & Arkeoloji & $1,22523^{*}$ & 0,038 \\
\hline & & Türk dili ve edebiyatı & $1,47297^{*}$ & 0,013 \\
\hline & Türk dili ve edebiyatı & Moleküler biy. ve gen, & & \\
\hline \multirow[t]{8}{*}{ Özgüven eksikliği } & \multirow[t]{3}{*}{ Matematik } & Sosyoloji & $-2,70261^{*}$ & 0,013 \\
\hline & & Tarih & $-3,07640^{*}$ & 0,003 \\
\hline & & Türk dili ve edebiyatı & $-2,26559^{*}$ & 0,029 \\
\hline & \multirow{4}{*}{$\begin{array}{l}\text { Moleküler } \\
\text { genetik, }\end{array}$} & veArkeoloji & $-2,09580^{*}$ & 0,010 \\
\hline & & Sosyoloji & $-3,60714^{*}$ & 0,000 \\
\hline & & Tarih & $-3,98094^{*}$ & 0,000 \\
\hline & & Türk dili ve edebiyatı & $-3,17013^{*}$ & 0,000 \\
\hline & Arkeoloji & Tarih & $-1,88514^{*}$ & 0,012 \\
\hline
\end{tabular}

Ortalamalar arası farklılıklar Tablo 8'de sunulmuştur. Faktör boyutlarında bölümlerin ortalamaları incelendiğinde Matematik ile Moleküler Biyoloji ve Genetik bölümleri ortalama değerlerinin Tarih, Sosyoloji, Türk Dili ve Edebiyatı ve Arkeoloji bölüm ortalama değerlerinden düşük olduğu görülmüştür. Türk Dili ve Edebiyatı bölümü ortalama değerinin Arkeoloji, Sosyoloji ve Tarih bölümlerinden düşük olduğu görülmüştür. 


\subsubsection{Cinsiyete göre İşsizlik Kaygısı Bakımından Farklıkların Belirlenmesi}

Kadın ile erkek öğrenciler arasında işsizlik kaygısı ifadelerine verdikleri yanıtlar bakımından farklılık olup olmadığının belirlenmesinde bağımsız örneklemler $\mathrm{t}$ testiyle uygulanmıştır. Öğrencilerin cinsiyetlerine göre istihdamdaki zorluklar ( $p=0,600>\alpha=0,05)$, çevresel ve sosyal bask1 ( $p=0,243>\alpha=0,05)$ için $\mathrm{H}_{1,3}$ hipotezi kabul edilmemiştir. Niteliksel olarak bilgi ve beceri eksikliği $(p=0,015<\alpha=0,05)$ ve kişisel karamsarlık ve özgüven eksikliği $(p=0,015<\alpha=0,05)$ için $\mathrm{H}_{1,3}$ hipotezi kabul edilmiştir. Farklılıkların belirlendiği niteliksel olarak bilgi ve beceri eksikliği ile kişisel karamsarlık ve özgüven eksikliği faktörlerinin ortalamaları incelendiğinde erkek öğrenciler kadın öğrencilere kıyasla daha yüksek puanlar vermiştir.

Tablo 9. Cinsiyete göre işsizlik kaygısı bakımından farklıkların bağımsız örneklemler t testi bulguları

\begin{tabular}{|c|c|c|c|c|c|}
\hline FAKTÖRLER & Cinsiyet & $\mathrm{n}$ & Ortalama & $\mathrm{t}$ & $\mathrm{p}$ \\
\hline \multirow{2}{*}{ İstihdamdaki zorluklar } & Kadın & 122 & 14,4283 & \multirow{2}{*}{$-0,525$} & \multirow{2}{*}{0,600} \\
\hline & Erkek & 58 & 14,8685 & & \\
\hline \multirow{2}{*}{ Çevresel ve sosyal baskı } & Kadın & 122 & 6,5055 & \multirow{2}{*}{$-1,172$} & \multirow{2}{*}{0,243} \\
\hline & Erkek & 58 & 6,9856 & & \\
\hline \multirow{2}{*}{ Niteliksel olarak bilgi ve beceri eksikliği } & Kadın & 122 & 2,8996 & \multirow{2}{*}{$-2,444$} & \multirow{2}{*}{0,015} \\
\hline & Erkek & 58 & 3,2371 & & \\
\hline \multirow{2}{*}{ Kişisel karamsarlık ve özgüven eksikliği } & Kadın & 122 & 9,2316 & \multirow{2}{*}{$-2,457$} & \multirow{2}{*}{0,015} \\
\hline & Erkek & 58 & 10,5647 & & \\
\hline
\end{tabular}

\subsubsection{Ailede Ticaretle Uğraşan Olma Durumuna göre İşsizlik Kaygısı Bakımından Farklıkların Belirlenmesi}

Ailede ticaretle uğraşan olup olmama durumuna göre işsizlik kaygısı ifadelerine verilen yanıtlar bakımından farklılık bağımsız örneklemler $\mathrm{t}$ testiyle sınanmıştır. İşsizlik kaygısı faktörlerinin tümü için $(p>\alpha=0,05) \mathrm{H}_{1,4}$ hipotezi kabul edilmemiştir. Ticaretle uğraşan bir aile üyesi olup olmaması durumuna göre öğrencilerin işsizlik kaygı düzeyleri bakımından anlamlı farklılık olmadığı söylenir.

Tablo 10. Ailede ticaretle uğraşan olma durumuna göre işsizlik kaygısı bakımından farklıkların bağımsız örneklemler $t$ testi bulguları

\begin{tabular}{|c|c|c|c|c|c|}
\hline & Ticaretle uğraşan & n & Ortalama & t & $\mathrm{p}$ \\
\hline \multirow{2}{*}{ İstihdamdaki zorluklar } & Var & 44 & 14,9091 & \multirow[t]{2}{*}{0,492} & \multirow{2}{*}{0,623} \\
\hline & Yok & 136 & 14,4605 & & \\
\hline \multirow{2}{*}{ Çevresel ve sosyal baskı } & Var & 44 & 6,1136 & \multirow[t]{2}{*}{$-1,630$} & \multirow{2}{*}{0,105} \\
\hline & Yok & 136 & 6,8370 & & \\
\hline \multirow{2}{*}{ Niteliksel olarak bilgi ve beceri eksikliği } & Var & 44 & 3,1875 & \multirow[t]{2}{*}{1,564} & \multirow{2}{*}{0,120} \\
\hline & Yok & 136 & 2,9504 & & \\
\hline \multirow{2}{*}{ Kişisel karamsarlık ve özgüven eksikliği } & Var & 44 & 10,3807 & \multirow[t]{2}{*}{1,599} & \multirow{2}{*}{0,112} \\
\hline & Yok & 136 & 9,4283 & & \\
\hline
\end{tabular}

Year 4/ 2020, Volume-4, Issue-3 | WwW.ispecjournal.org 


\subsubsection{Yerleşim Yerlerine göre İşsizlik Kaygısı Bakımından Farklıkların Belirlenmesi}

Yerleşim yerlerine göre işsizlik kaygısı bakımından farklıkların sınanmasında tek yönlü varyans analizi uygulanmıştır.

Tablo 11. Yerleşim yerlerine göre işsizlik kaygısı boyutları varyans analizi bulguları

\begin{tabular}{|l|l|l|}
\hline & $\mathrm{F}$ & $\mathrm{p}$ \\
\hline İstihdamdaki zorluklar & 1,263 & 0,285 \\
\hline Çevresel ve sosyal bask1 & 3,701 & 0,027 \\
\hline Niteliksel olarak bilgi ve beceri eksikliği & 1,149 & 0,319 \\
\hline Özgüven eksikliği & 3,672 & 0,027 \\
\hline
\end{tabular}

Yerleşim yerlerine göre çevresel ve sosyal bask1 $(p=0,027<\alpha=0,05)$, özgüven eksikliği ( $\mathrm{p}=0,027<\alpha=0,05)$ için $\mathrm{H}_{1,5}$ hipotezi istatistiksel olarak anlamlı bulunmuştur. Anlamlı olduğu belirlenen çevresel ve sosyal baskı ile özgüven eksikliği için ortalamalar arası fark kontrolü testlerinden varyansları homojen belirlendiği için LSD testi uygulanmıştır.

Tablo 12. Yerleșim yerlerine göre işsizlik kaygısı boyutları LSD testi bulguları

\begin{tabular}{|c|c|c|c|c|}
\hline & (I) yerleşim yeri & (J) yerleşim yeriniz & $\begin{array}{l}\text { Ortalama farklar (I- } \\
\text { J) }\end{array}$ & p \\
\hline \multirow[t]{3}{*}{ Çevresel ve sosyal baskı } & \multirow[t]{2}{*}{ Köy } & kasaba-ilçe &, 40374 & 0,495 \\
\hline & & şehir merkezi & $1,28022^{*}$ & 0,024 \\
\hline & kasaba-ilçe & şehir merkezi & $87648^{*}$ & 0,036 \\
\hline \multirow[t]{3}{*}{ Özgüven eksikliği } & \multirow[t]{2}{*}{ köy } & kasaba-ilçe & 1,36584 & 0,086 \\
\hline & & şehir merkezi & $2,02610^{*}$ & 0,008 \\
\hline & kasaba-ilçe & şehir merkezi &, 66026 & 0,237 \\
\hline
\end{tabular}

*: Ortalama farkları $\alpha=0,05$ düzeyinde anlamlıdır.

Çevresel ve sosyal baskı için köyden ile şehir merkezinden gelen öğrenciler arasında farklılık olduğu $(p=0,024<\alpha=0,05)$ belirlenmiştir. Ortalamaları incelendiğinde köy yerleşim yerinden gelenlerin ortalama değeri $(7,44)$ şehir merkezinden gelenlere $(6,1685)$ kıyasla daha yüksektir. Özgüven eksikliği için köyden ile şehir merkezinden gelen öğrenciler arasında farklılık olduğu $(\mathrm{p}=0,008<\alpha=0,05)$ belirlenmiştir. Ortalamaları incelendiğinde ortalama değeri köy yerleşim yerinden gelenlerin $(11,16)$ şehir merkezinden gelenlere $(9,135)$ kıyasla daha yüksektir. Dolayısıyla köy merkezinden gelenlerin şehir merkezinden gelenlere kıyasla çevresel ve sosyal baskı ve Özgüven eksikliği daha fazla hissettiği söylenebilir. 


\subsubsection{6. Öğrenci Genel Not Ortalamasına göre İşsizlik Kaygısı Bakımından Farklıkların Belirlenmesi}

Öğrenci genel not ortalamasına göre işsizlik kaygısı bakımından farklıkların sınanmasında tek yönlü varyans analizi uygulanmıştır.

Tablo 13. Öğrenci genel not ortalamasına göre işsizlik kaygısı boyutları varyans analizi bulguları

\begin{tabular}{|l|l|l|}
\hline & F & p \\
\hline İstihdamdaki zorluklar & 6,057 & 0,003 \\
\hline Çevresel ve sosyal bask1 & 0,368 & 0,692 \\
\hline Niteliksel olarak bilgi ve beceri eksikliği & 2,956 & 0,055 \\
\hline Özgüven eksikliği & 1,358 & 0,260 \\
\hline
\end{tabular}

Öğrenci genel not ortalamasına (GANO) göre istihdamdaki zorluklar $(p=0,003<\alpha=0,05)$ için $\mathrm{H}_{1,6}$ hipotezi anlamlı bulunmuştur. Farklılıkların belirlendiği istihdamdaki zorluklar faktörü için ortalamalar arası fark kontrolü testlerinden varyansları homojen belirlendiği için LSD testi uygulanmıştır.

Tablo 14. Öğrenci genel not ortalamasına göre işsizlik kaygısı boyutları LSD testi bulguları

\begin{tabular}{|l|l|l|l|l|}
\hline & (I) GANO & (J) GANO & Ortalama farklar (I-J) & p \\
\hline İstihdamdaki zorluklar & $1,01-2,00$ & $2,01-3,00$ & $-4,26721^{*}$ &, 001 \\
\cline { 3 - 5 } & & $3,01-4,00$ & $-2,84430^{*}$ &, 037 \\
\cline { 2 - 5 } & $2,01-3,00$ & $3,01-4,00$ & 1,42291 &, 092 \\
\hline
\end{tabular}

*: Ortalama farkları $\alpha=0,05$ düzeyinde anlamlıdır.

İşsizlik kaygısı boyutlarından istihdamdaki zorluklar için genel not ortalaması 1,01-2,00 arasında olan öğrencilerin genel not ortalaması 2,01-3,00 ile 3,01-4,00 olan öğrencilerden farklı olduğu belirlenmiştir $(\mathrm{p}<\alpha=0,05)$. Ortalamalar incelendiğinde genel not ortalaması 1,012,00 arasında olan öğrencilerin ortalama değeri $(11,20) ; 2,01-3,00$ arasında olan öğrencilerin ortalama değeri $(15,47)$ ve $3,01-4,00$ arasında olan öğrencilerin ortalama değerine $(14,05)$ kıyasla daha düşüktür. 
Öğrencilerin ailesinde ticaretle uğraşan biri olup olmamasına; iş deneyimi olması durumuna; anne eğitimine; baba eğitimine ve aile gelirine göre işsizlik kaygısı bakımından farklılık olmadığ belirlenmiştir ( $\mathrm{p}>\alpha=0,05)$. $\mathrm{H}_{1,4}, \mathrm{H}_{1,7}, \mathrm{H}_{1,8}, \mathrm{H}_{1,9}$ ve $\mathrm{H}_{1,10}$ hipotezleri istatistiksel olarak anlamlı bulunmamıştır.

\section{Sonuç}

$\mathrm{Bu}$ çalışmayla, işsizlik kaygısı yüzde dağılımları ve ortancaları incelenmiştir. Balkaya (2017) çalışması işsizlik kaygısı ölçeği kullanılmıştır. Faktör analizi sonucu istihdamdaki zorluklar; çevresel ve sosyal baskı; niteliksel olarak bilgi ve beceri eksikliği ile kişisel karamsarlık ve özgüven eksikliği olarak adlandırılan dört faktör belirlenmiştir. Demografik özelliklere göre işsizlik kaygısı boyutları farklılıkları incelenmiştir. Uygulama çalışması sonucunda elde edilen bulgulardan şu sonuçlara ulaşılmıştır.

- Öğrencilerin işsizlik kaygısı ifadelerine çoğunluk katılım düzeyleri ortancaları "Kararsızım" ile "Katıliyorum" olmuştur. Ancak, "Ailemden yakın gelecekte bir iş sahibi olmam için bask1 görüyorum" ifadesi ortancası 2: Katılmıyorum olmuştur. Ailelerin çoğunluğunun yakın gelecekte bir iş sahibi olmalarına baskı yapmadı̆̆ yüzde dağılımından da görülmüş̧ür.

- Yüzde dağılımları incelendiğinde öğrencilerin çoğunluğunun işsizlik kaygısı yaşadığını belirlenmiştir. Bununla birlikte, ailelerinden yakın gelecekte iş sahibi olma konusunda bask1 görmedikleri; iş olmaması nedeniyle okulu bırakma düşüncesi olmadığı; kendisini nitelikli bir işgücü olarak gördüğü; kendisini gelecekte çalışmak istediği alanla ilgili bilgi ve beceri sahibi olarak gördüğü ifadelerine ise öğrencilerin çoğunluğu katıldığı yönünde yanıt vermiştir.

- En yüksek yüzde dağılımı \%77,2 ile "Yakın gelecekte içinde bulunacağım işgücü piyasasında durumum belirsizdir." ifadesine aittir. İkinci sırada en yüksek yüzde dağılımı \%73,9 ile "Türkiye'de mezun olacağım bölümle ilgili iş olanakları kısıtlıdır." ifadesidir. Üçüncü sırada en yüksek yüzde dağılımı \%70 ile "Okuduğum bölümle ilgili iş olanaklarının yeterli olduğunu düşünmüyorum." Genel itibariyle tüm ifadeler yüzde dağılımları incelendiğinde öğrencilerin gelecekle ilgili işsizlik kaygısı duydukları gözlenmiştir.

- Faktör boyutlarında tanımlayıcı istatistiklerden ortalamalar incelendiğinde "İstihdamdaki zorluklar" öğrencilerin en çok sıkıntı duyduğu konu olmuştur.

- "Niteliksel olarak bilgi ve beceri eksikliği" en düşük ortalama puanlı faktör boyutu olmuştur. Öğrencilerin çoğunluğunun kendilerini niteliksel olarak bilgi ve beceri yönünden eksik hissetmedikleri yorumu yapılabilir. 
- Çalışmanın hipotezlerinin sınandığı analizler sonucu demografik özelliklere göre farlılıklar belirlenmiştir.

Fen ile sosyal bilimler alanı öğrencileri arasında istihdamdaki zorluklar; çevresel ve sosyal baskı ile kişisel karamsarlık ve özgüven eksikliği bakımından farklılık olduğu belirlenmiştir. $\mathrm{Bu}$ faktörler için sosyal bilimler alan öğrencilerinin fen bilimleri alan öğrencilerine kıyasla daha yüksek kaygı duyduğu söylenebilir. Alanlara göre niteliksel olarak bilgi ve beceri eksikliği yönünden farklılık olmadığı belirlenmiştir.

Bölümlere göre farklılıkların belirlendiği İstihdamdaki zorluklar; Çevresel ve sosyal baskı ile Özgüven eksikliği işsizlik kaygısı faktörlerinde ortalamalar incelenmiştir. Matematik ile Moleküler Biyoloji ve Genetik bölümleri öğrencilerinin bu faktör boyutlarında Tarih, Sosyoloji, Türk Dili ve Edebiyatı ve Arkeoloji bölümleri öğrencilerine kıyasla daha az işsizlik kaygısı yaşadığı tespit edilmiştir. Türk Dili ve Edebiyatı bölümü öğrencilerinin ise Arkeoloji, Sosyoloji ve Tarih bölümlerine kıyasla daha az işsizlik kaygısı yaşadığı belirlenmiştir.

Cinsiyete göre işsizlik kaygısı boyutlarından niteliksel olarak bilgi ve beceri eksikliği ile kişisel karamsarlık ve özgüven eksikliği faktörlerinde farklılıklar olduğu belirlenmiştir. $\mathrm{Bu}$ faktörler için ortalamaları incelendiğinde erkek öğrencilerin kadın öğrencilere kıyasla daha yüksek işsizlik kaygısı duyduğu görülmüştür.

Yerleşim yerlerine göre işsizlik kaygısı boyutlarından çevresel ve sosyal baskı ile özgüven eksikliği faktörlerinde farkl1lıklar belirlenmiştir. Her iki faktör için de köy yerleşim yerinden gelenlerin şehir merkezinden gelenlere kıyasla çevresel ve sosyal baskı ile özgüven eksikliğini daha fazla hissettiği belirlenmiştir.

Genel not ortalamasına göre işsizlik kaygısı boyutlarından istihdamdaki zorluklar faktörü için farkl11ık olduğu belirlenmiştir. GANO'su 1,01-2,00 arasında olan öğrencilerin GANO'su 2,00-4,00 arasında olan öğrencilere kıyasla daha düşük seviyede işsizlik kaygısı yaşadığı yorumu yapılmıştır.

Ailede ticaretle uğraşan biri olup olmamasına; iş deneyimi olması durumuna; anne eğitimine; baba eğitimine göre işsizlik kaygısı bakımından öğrenciler aralarında farklılık olmadığı belirlenmiştir.

Literatür çalışmalarından öğrenci demografik özelliklerine göre işsizlik kaygı düzeylerinin farklılık gösterdiği belirlenmiştir. Dursun ve Aytaç (2009) çalışmalarında erkek öğrencilerin kadın öğrencilere kıyasla işsizlik kaygı puanlarının daha düşük olduğu belirlenmiştir. Son sınıf üniversite öğrencileri üzerine yaptığı araştırmada iş deneyiminin işsizlik kaygısını azalttığı belirlenmiştir. Daha önce bir işte çalışmış olanların işsizlik kaygısının düşük olduğu belirlenmiştir. Doğan ve Çoban (2009) üniversite öğrencileriyle yapılan çalışmasıyla ümidi olmayan veya karamsar olan öğrencilerde yüksek oranda işsizlik kaygısı yaşadıklarını tespit etmiştir. Tektaş (2014) üniversite mezunlarının kaygı düzeylerinin incelenmesinde erkek mezun katılımcılarının durumluluk-sürekli kaygı düzeyleri kadın mezun katılımcılara kıyasla daha düşük olduğu belirlenmiştir. Tekin (2015) çalışmasında öğrencilerin üniversiteden 
mezun olduktan sonra ailelerine yük olmak istemedikleri, ailelerinin çocuklarının bir an önce işe yerleşmesini istemeleri ve kendi benliğini tehdit edici bir unsur olarak algılamalarına iş bulamama kaygısı yaşamalarına neden olduğunu belirtmiştir. Balkaya (2017) çalışmasında üniversite öğrencilerinin işsizlik kaygı düzeylerinin cinsiyet, sosyal destek, ailevi özelliklere göre farklılık gösterdiği belirlenmiştir. Sağlık açısından işsizlikle mücadele edilmelidir. Erkekler ve kızlar farklı şekilde etkilenir. Erkeklerin tepkileri daha görünür olma eğilimindeyken, kızların tepkileri daha görünmez olma eğilimindedir (Hammarström, 1994).

Mütevellioğlu vd. (2010) çalışmasıyla üniversiteyi bitirince gençlerin çok zorlanmadan uygun bir iş bulabilme beklentisi üçte birinden azının umduğunu belirlemiştir. Öğrencinin cinsiyeti, geliri ve ailesinin gelir düzeyi değişkenleri ile gençlerin iş bulabilme umudu arasında ilişki olduğu saptanmıştır. Erkek öğrencilerin kız öğrencilere kıyasla iş bulma konusunda daha umutlu oldukları belirlenmiştir.

Üniversite son sınıf öğrencilerinde mezun olunduktan sonra artık öğrencilik yaşamının bitmesiyle gerçek hayatta rolün alınmasına yönelik planlar, iş seçimi, çeşitli sorumluluklar ve iş bulamama korkusu öğrencilerde kaygıya neden olan etmenlerden bazıları olarak ortaya çıkmaktadır (Çakmak ve Hevedanlı, 2004: 3).

İş bulmaktan endişe etmek birçok öğrenciyi mutsuz etmekte ve kaygı duymalarına neden olmaktadır. Türkiye'de birçok üniversite mezunu istihdam eksikliği nedeniyle asıl mesleği dışında bir alanda çalışmak zorunda kalmaktadır (Ateş, 2019).

2018 yılı TÜİK 2017 yılı Mart bülteninde yayınlanan veriler, yükseköğretim mezunlarında işsizlik yüzdesinin \%12,2 seviyelerinde olduğunu göstermektedir. Bu değer yaklaşık bir milyon üniversite mezunu gencin işsiz olduğu anlamına gelmektedir (TÜİK, 2019).

Günümüzde genç işsizliği sorununun çözümündeki anahtar unsur, gençlerin işgücü kalitesini yükseltmekten geçmektedir. Gençlerin işgücü kalitesi ve işini doğru yapmasını bilmesini, iyi bir iş disiplini ve ahlâkına sahip olmalarını sağlamak, bilgi miktarı ve derinliği, yönetimsel beceri, yaratıcılık ve değişen çevresel koşullara uyum sağlayabilme yeteneğini arttırmalarına yardımcı olmaktır. Eğitim ve iş deneyimi unsurlarından etkilenen ve belirlenen kaliteli işgücü oluşum sürecinin altında ülkelerin uyguladıkları eğitim sistemleri yatmaktadır (İçli, 2001).

Gençlerin işsizlik sorunun kendi hataları olmadığını ve yalnız olmadıklarını bilmeleri gerekmektedir. Gençler işsizlik kaygısını gidermek için her firsatı değerlendirmelidir. Kaygı düzeyi yüksek hissedildiğinde psikolog/psikiyatristlerden yardım almaları önerilebilir.

Genç işsizliği için herkese uyan tek bir çözüm bulunmamaktadır. Bu sebeple genç işsizliği sorunlardan bir veya daha fazlasını ele alan çok sayıda özelleştirilmiş çözüm oluşturmak gerekmektedir. Üniversitelerin müfredatları bugünün iş piyasasının ihtiyaçları ile uyumlu değil (Kelly, 2019). Beceri talebi ve arzı arasındaki uyumu iyileştirmek için eğitim sistemleri yeniden düzenlenmelidir. Eğitim sistemiyle işgücü piyasasında mevcut işler için yeterli beceriye sahip gençler yetiştirilmelidir. Akademik ve mesleki yeterliliklere sahip daha dengeli bir profil elde etmemizi sağlamak için mesleki eğitim ve öğretimin arttırılması gerekmektedir.

Year 4/ 2020, Volume-4, Issue-3 | www.ispecjournal.org 
Önerilen stratejilerin işgücü piyasası tarafından yönlendirilmesini ve tam olarak desteklenmesini sağlamak için endüstri ortaklarının çözümün merkezinde olması gerekmektedir. Nihai hedef, gençler için daha fazla ve daha iyi istihdam firsatları yaratmak ve bununla bağlantılı olarak okuldan işe geçişi düzeltmek için ulusal ve uluslararası bir çerçeve oluşturmak olmalıdır (ETUC, 2013 Aktaran: Vogel, 2015: 2).

\section{Kaynakça}

Akgün, M. (2019). Türkiye'de genç işsizlik sorunu ve bu sorunun çözümüne yönelik istihdam politikaları [Yayınlanmamış yüksek lisans tezi]. Maltepe Üniversitesi.

Ateş, S. S. (2019), Anxiety of unemployment before the graduation: research on university students in the aviation departments. International Journal Entrepreneurship and Management Inquiries, 3(5), 165 - 174.

Aytaç, S. ve Keser, A. (2002). İşsizliğin çalı̧an birey üzerindeki etkisi: İşsizlik kaygısı. iş, güç. Endüstri İlişkileri ve İnsan Kaynakları Dergisi, 4(2), http://www.isguc.org/?p=article\&id=48\&cilt=4\&sayi=2\&yil=2002.

Balkaya, E. (2017), Üniversite son sınıf öğrencilerinde işsizlik kaygısı ve girişimcilik niyeti ilişkisi: TRA1 bölgesi örneği [Yayınlanmamış yüksek lisans tezi]. Atatürk Üniversitesi.

Çakmak, Ö., Hevedanlı, M. (2004). Biyoloji Öğretmen Adaylarının Kaygılarını Etkileyen Etmenler. 13. Ulusal Eğitim Bilimleri Kurultayı, 6-9 Temmuz, İnönü Üniversitesi,

Doğan, T. ve Çoban, A. E. (2009), Eğitim fakültesi öğrencilerinin öğretmenlik mesleğine yönelik tutumları ile kaygı düzeyleri arasındaki ilişkinin incelenmesi. Eğitim ve Bilim Dergisi, 34(153), 157-168.

Dursun, S. ve Aytaç, S. (2009). Üniversite öğrencileri arasında işsizlik kaygısı. Uludağ Üniversitesi İktisadi ve İdari Bilimler Fakültesi Dergisi, 28(1), 71-84.

Ersoy-Kart, M. \& Erdost, H. E. (2008). Unemployment worries among turkish university students. social behavior nnd personality. Social Behavior and Personality: An İnternational Journal, 36(2), 275-288.

https://doi.org/10.2224/sbp.2008.36.2.275

Hammarström, A. (1994). Health consequences of youth unemployment--review from a gender perspective. Social Science and Medicine, 38(1), 699-709.

https://doi.org/10.1016/0277-9536(94)90460-X

HÜRRIYET (2016, 9 Şubat). Üniversite araştırmasında ilginç sonuçlar, https://www.hurriyet.com.tr/gundem/universite-arastirmasinda-ilginc-sonuclar-40052030

Year 4/ 2020, Volume-4, Issue-3 | www.ispecjournal.org 
ILO 2018. Uluslararası Çalışma Örgütü, https://www.ilo.org/wcmsp5/groups/public/--europe/---ro-geneva/---ilo-ankara/documents/publication/wcms_627045.pdf.

İçli, G. (2001). Eğitim, istihdam ve teknoloji. Pamukkale Üniversitesi Eğitim Fakültesi Dergisi, 9, 67-70.

Kaiser, F. H. (1974). An index of factorial simplicity. Psychometrika, 1(39), 31-36. https://doi.org/10.1007/BF02291575

Kalaycı, Ş. (2006). SPSS uygulamalı çok değişkenli istatistik teknikleri. Asil Yayınevi.

Kelly, J. (2019). Recent College Graduates Have The Highest Unemployment Rate in Decades-Here's Why Universities Are to Blame, Forbes, https://www.forbes.com/sites/jackkelly/2019/11/14/recent-college-graduates-have-thehighest-unemployment-rate-in-decadesheres-why-universities-are-toblame/\#296bf413320b

Kish, L. (1965). Survey Sampling, John Wiley \& Sons Inc.

Koçak, O. ve Çepni, S. (2017). Üniversite öğrencilerinin çalışma hayatına dair beklentilerinin değerlendirilmesi: Yalova Üniversitesi öğrencileri örneği, Trakya Üniversitesi İktisadi ve İdari Bilimler Fakültesi E-Dergi, 6(1), 241-265.

Murat, S. (1991). Sosyo-ekonomik boyutlarıyla genel olarak ve Türkiye'de gençlerin işsizliği [Yayınlanmamış doktora tezi]. İstanbul Üniversitesi.

Mütevellioğlu, N., Zanbak, M. ve Mert, M. (2010).İşsizlik, üniversiteli gençlik ve gelecek: bir alan araştırmasının bulguları. C.Ü. İktisadi ve İdari Bilimler Dergisi, 11(1), 207-229.

Önocak, D. (2008). İşsizlik sürecinin bireyler üzerindeki psikolojik ve sosyoekonomik etkileri (Sivas Örneği) [Yayınlanmamış yüksek lisans tezi]. Cumhuriyet Üniversitesi.

Özdamar, K. (1999). Paket programlar ile istatistiksel veri analizi, Kaan Kitabevi.

Özkan, M. A. (2013). Eğitim istihdam ilişkisi, İŞKUR Yayınları, 8, 48-51.

Savcı, İ. (2007). Genç İşsizliği: Eğitim ve İstihdamda Sorunlar, Çözüm Arayışları, Genç İşsizliği Sempozyumu, TİSK Akademi, 2(1), 87-108.

Tekin A. N. (2015). Üniversite öğrencilerinde işsizlik kaygısı: Süleyman Demirel Üniversitesi öğrencileri üzerinde bir araştırma [Yayınlanmamış yüksek lisans tezi]. Süleyman Demirel Üniversitesi.

Tektaş, N. (2014). Üniversite mezunlarının kaygı düzeylerinin incelenmesi. Selçuk Üniversitesi Sosyal Bilimler Enstitüsü Dergisi. Dr. Mehmet Yıldız Özel Sayısı, 243-253.

Year 4/ 2020, Volume-4, Issue-3 | WwW.ispecjournal.org 
TÜİK, (2019), Türkiye İstatistik Kurumu Ekim 2019 dönemi işgücü istatistikleri, Ankara.

TÜİK, (2020). Türkiye İstatistik Kurumu, İşgücü İstatistikleri 2014-2019

http://www.tuik.gov.tr/PreTablo.do?alt_id=1007.

Vogel P. ( 2015), Generation Jobless?, St Martin's Press .

https://doi.org/10.1057/9781137375940

Wanberg, R. C., Carmichael, D. H. \& Downey, G. R. (1999). Satisfaction at last job and unemployment: A new look, Journal of Organizational Behavior, 20(1), 121-131. https://doi.org/10.1002/(SICI)1099-1379(199901)20:1<121::AID-JOB870>3.0.CO;2-6

Winefield, H. A. (1997). Introduction to the psychological effects of youth unemployment: international perspectives, Journal of Adolescence, Vol. 20 Issue 3, pp. 237-241. https://doi.org/10.1006/jado.1997.0082

Yavuzer, H., Demir, İ., Meşeci, F. ve Sertelin, Ç. (2005). Günümüz Gençliğinin Gelecek Beklentileri, Hasan Ali Yücel Eğitim Fakültesi Dergisi, 2, 93-103. 